\title{
Pengujian Fraud Diamond Theory Pada Indikasi Financial Statement Fraud Di Indonesia
}

\author{
Ni Kadek Suparmini ${ }^{1}$ \\ Fakultas Ekonomi dan Bisnis \\ Universitas Udayana, Indonesia \\ Email: rita.suparmini@gmail.com
}

\author{
Dodik Ariyanto \\ Fakultas Ekonomi dan Bisnis \\ Universitas Udayana, Indonesia
}

\section{Made Andika Pradnyana Wistawan ${ }^{3}$ Fakultas Ekonomi dan Bisnis Universitas Udayana, Indonesia}

\begin{abstract}
ABSTRAK
Penelitian ini bertujuan untuk mendapatkan bukti empiris tentang fraud diamond theory. Penelitian dilakukan pada perusahaan manufaktur yang terdaftar di Bursa Efek Indonesia (BEI) periode 2015-2017. Metode penetuan sampel yang digunakan nonprobability sampling dengan teknik purposive sampling. Terdapat 145 perusahaan sebagai populasi dengan jumlah 66 perusahaan sebagai sampel. Teknik analisis data yang digunakan adalah regresi linier berganda. Berdasarkan hasil analisis, dinyatakan bahwa nature of industry berpengaruh negatif pada indikasi financial statement fraud sedangkan personal financial need, auditor firm size, dan change of directors tidak berpengaruh pada indikasi financial statement fraud. Penelitian memberikan implikasi bagi shareholder, regulator, ataupun pihak yang menggunakan informasi dalam laporan keuangan sebagai pertimbangan dalam memberikan penilaian terhadap peluang terjadinya tindakan kecurangan atas laporan keuangan perusahaan.
\end{abstract}

Kata Kunci: Diamond Fraud; Financial Statement Fraud.

\section{Can Fraud Diamond Theory detect Fraud Financial Statement In Indonesia?}

\section{ABSTRACT}

This study aims to obtain empirical evidence of fraud diamond theory. This research was conducted on manufacturing companies listed on the Indonesia Stock Exchange (BEI) for the 2015-2017 period. The sample determination method used is nonprobability sampling with purposive sampling technique. There are 145 companies as a population with a total of 66 companies as samples. The data analysis technique used is multiple linear regression. Based on the results of the analysis, it was stated that the nature of industry had a negative effect on indications of financial statement fraud while financial need, auditor firm size, and change of directors had no effect on indications of financial statement fraud. This study has implications for shareholders, regulators, or parties who use information in financial statements as a consideration in providing an assessment of the chances of fraudulent actions on the company's financial statements.

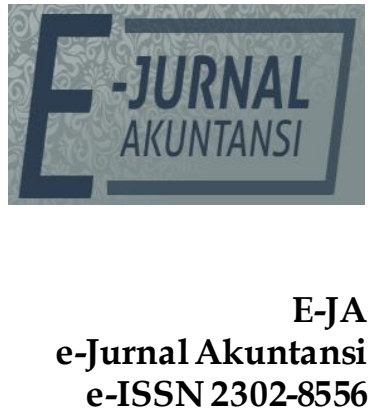

Vol. 30 No. 6

Denpasar, Juni 2020 Hal. 1441-1457

Artikel Masuk: 24 November 2018

Tanggal Diterima: 25 Juni 2020

Keywords: $\quad$ Diamond Fraud; Financial Statement Fraud.

This Article is Avalilable in: https://ojs.unud.ac.id/index.php/Akuntansi/index 


\section{PENDAHULUAN}

Kinerja perusahaan salah satunya dapat diukur dari informasi yang terdapat dalam laporan keuangan perusahaan. Laporan keuangan merupakan sebuah cerminan bagi para pengguna informasi keuangan untuk mengetahui bagaimana kondisi keuangan suatu perusahaan (Sari et al., 2018). Tujuan laporan keuangan yang tertuang dalam Pedoman Standar Akuntansi Keuangan (PSAK) No. 1 Revisi 2017, yakni memberikan informasi terkait posisi keuangan, kinerja keuangan, serta arus kas entitas yang bermanfaat bagi pengguna laporan keuangan dalam pembuatan keputusan ekonomi.

Menyadari pentingnya informasi yang terdapat dalam laporan keuangan mengakibatkan para manajer termotivasi untuk menggambarkan kondisi perusahaan sebaik mungkin. Motivasi atau dorongan untuk selalu terlihat baik dibandingkan dengan para pesaingnya sering memaksa perusahaan untuk melakukan tindakan kecurangan, sehingga menyajikan informasi yang tidak semestinya dan merugikan banyak pihak.

Association of Certified Fraud Examiners atau (ACFE, 2016) mengatakan bahwa terdapat tiga kategori tindakan kecurangan yang dilakukan oleh pihak internal perusahaan. ACFE menggambarkannya dalam sebuah bagan kecurangan yang disebut dengan "Fraud Tree" atau "Pohon Kecurangan". Pohon tersebut terdapat tiga cabang, yaitu korupsi, penyalahgunaan aset, dan manipulasi laporan keuangan. Ketiga jenis tindak kecurangan tersebut, manipulasi laporan keuangan menimbulkan kerugian paling besar bagi perusahaan. Kerugian tersebut terjadi karena pelaku tindak manipulasi laporan keuangan didominasi oleh internal perusahaan yakni pihak manajer atau pihak yang memiliki wewenang lebih di dalam perusahaan, sehingga hal tersebut mempermudah mereka untuk melakukan tindakan tersebut.

Menurut Yusof (2015) laporan keuangan seringkali disalahgunakan dan dijadikan sebagai alat dalam melaksanakan praktik kecurangan maupun manipulasi informasi yang disebut dengan financial statement fraud atau kecurangan atas laporan keuangan. Association of Certified Fraud Examiners (ACFE, 2016) fraud atau kecurangan merupakan tindakan penipuan maupun kekeliruan seseorang atau entitas yang mengetahui bahwa kekeliruan tersebut dapat menghasilkan dampak yang tidak baik kepada suatu entitas atau pihak lain.

Terkuaknya kasus kecurangan yang menghebohkan dunia pada tahun 2002 melibatkan perusahaan ternama yakni Enron. Perusahaan skala internasional bergerak di bidang energi dengan kantor akuntan publik yaitu KAP Arthur Andersen telah melakukan pemanipulasian laporan keuangan dengan mencatat keuntungan sebesar 600 juta Dolar Amerika pada saat perusahaan mengalami kerugian. Akibat dari kasus ini adalah gugatan terhadap perusahaan sebesar 7,18 miliar Dolar Amerika (Liputan6.com, 2016).

Kasus kecurangan laporan keuangan tidak hanya terjadi di perusahaan berskala internasional saja, Indonesia pun sempat dikagetkan dengan kasus kecurangan pelaporan keuangan dilakukan oleh PT. Timah Persero Tbk (TINS). Kasus ini berawal dari tuntutan Ikatan Karyawan Timah terhadap direksi PT. Timah Tbk yang dinilai telah melakukan kesalahan serta kelalaian semasa menjabat tiga tahun sejak 2013. Ketua umum Ikatan Karyawan Timah (IKT), Ali 
Samsuri mengungkapkan direksi telah melakukan kebohongan publik melalui media. Pada press release laporan keuangan semester I tahun 2015, direksi menyatakan bahwa kinerja perusahaan positif. Namun kenyataan pada semester I tahun 2015 perusahaan rugi sebesar Rp. 59 miliar. Pada tahun 2013, utang perseroan hanya mencapai Rp. 263 miliar, namun jumlah utang tersebut meningkat hingga Rp. 2,3 triliun pada tahun 2015 (www.okezone.com).

Pada tahun 2015 juga, kasus Toshiba banyak diperbincangkan di khalayak umum. Perusahaan industri teknologi asal Jepang sejak tahun 1875, yang artinya sudah 140 tahun Toshiba mampu memikat hati masyarakat di seluruh dunia dengan menghasilkan produk berkualitas, dan layanan pelanggan yang excellent. Tim penyelidik independen menemukan bahwa CEO Toshiba yaitu Hisao Tanaka mengetahui bahwa perusahaan memanipulasi laporan keuangan dengan mencapai nilai sebesar 1,2 miliar Dolar Amerika, dan menyebabkan turunnya harga saham Toshiba sekitar $20 \%$. Tindakan tersebut telah mencoreng brand perusahaan yang sudah 140 tahun berdiri, dan perusahaan dikenakan denda yang nominalnya sangat besar. Sampai tahun 2017 kasus Toshiba ini pun masih menjadi isu hangat yang dibahas publik (Liputan6.com, 2015).

Banyaknya kasus kecurangan yang terjadi tidak selalu mendapatkan titik terang, kasus kecurangan terhadap laporan keuangan menunjukkan bahwa kecurangan atau fraud telah menjadi fenomena penting yang harus segera diselesaikan. Praktik kecurangan harus dicegah agar tidak merugikan berbagai pihak karena dampak negatif yang ditimbulkan. Pencegahan tersebut memerlukan serangkaian aturan yang berguna untuk mengatur aktivitas suatu perusahaan kearah yang lebih baik. Oleh karena itu, perlu diidentifikasi faktorfaktor yang menyebabkan terjadinya tindak kecurangan serta dapat digunakan sebagai pertimbangan bagi regulator dalam menetapkan aturan guna mencegah tindak kecurangan perusahaan.

Fraud diamond merupakan sebuah pandangan baru tentang fenomena fraud yang dikemukaan oleh Wolfe \& Hermanson (2004). Fraud diamond merupakan teori lanjutan atau penyempurnaan dari fraud triangle theory oleh Cressey (1953). Selain elemen tekanan (pressure), elemen kesempatan (opportunity), dan elemen rasionalisasi, Wolfe and Hermanson (2004) menambahkan satu elemen kualitatif yang diyakini mampu memiliki pengaruh terhadap fraud yakni elemen capability, sehingga menjadi empat elemen dikenal dengan fraud diamond theory yang menyempurnakan konsep fraud triangle atau segitiga kecurangan.

Elemen-elemen dari fraud diamond ini tidak bisa secara langsung untuk diteliti sehingga memerlukan proksi variabel. Elemen pertama dari fraud diamond yaitu tekanan (pressure) pada penelitian ini diproksikan dengan personal financial need. Personal financial need merupakan suatu kondisi dimana keuangan perusahaan turut dipengaruhi oleh kondisi keuangan para eksekutif perusahaan (Kusumawardhani, 2013). Financial statement fraud berkaitan erat dengan kepemilikan saham oleh orang dalam (personal financial need). Kondisi dimana sebagian saham dimiliki oleh manajer, direktur, maupun komisaris perusahaan secara otomatis menyebabkan yang bersangkutan merasa memiliki hak klaim 
atas penghasilan dan aktiva perusahaan sehingga akan mempengaruhi kondisi financial perusahaan.

Penelitian yang dilakukan oleh Surya et al., (2018) menyatakan bahwa personal financial need berpengaruh positif terhadap terjadinya praktik kecurangan, karena semakin pemilik internal perusahaan menggantungkan kebutuhan keuangan pribadinya atas kekayaan perusahaan maka tingkat kemungkinan praktik kecurangan pelaporan keuangan akan semakin potensial. Berbeda dengan penelitian Kusumaningsih (2017) menyatakan bahwa personal financial need berpengaruh negatif pada tindak kecurangan. Oleh karena itu, kepemilikan saham orang dalam atau personal financial need menjadi faktor yang patut diuji sebagai variabel yang berpengaruh terhadap praktik kecurangan.

Kesempatan (opportunity) atau elemen kedua dari fraud diamond ini juga menjadi unsur penting dalam terjadinya financial statement fraud. Kesempatan terjadinya kecurangan dalam perusahaan direfleksikan oleh sistem pengendalian internal perusahaan. Kesempatan dapat terjadi karena pengendalian internal yang lemah, pengawasan manajemen yang kurang baik, dan penggunaan jabatan yang dapat memberikan keuntungan pribadi. Nature of industry berkaitan dengan munculnya risiko bagi perusahaan yang berada dalam industri yang melibatkan pertimbangan dan estimasi yang signifikan jauh lebih besar.

Nature of industry merupakan keadaan ideal suatu perusahaan dalam industri. Kondisi piutang usaha adalah bentuk dari nature of industry yang dapat direspon dengan reaksi yang berbeda-beda dari pihak manajer perusahaan. Piutang dan persediaan memerlukan penilaian subjektif dalam memperkirakan tidak tertagihnya piutang dan obsulte inventory. Menurut Summers \& Sweeney (1998) dalam (Sihombing \& Rahardjo, 2014) menyarankan bahwa karena adanya penilaian subjektif dalam menentukkan nilai dari akun tersebut, pihak manajemen dapat menggunakan akun tersebut sebagai alat untuk memanipulasi laporan keuangan. Haryono (2017) menyatakan bahwa nature of industry berpengaruh terhadap financial statement fraud. Hal ini serupa diungkapkan oleh (Putriasih, 2016) bahwa keadaan ideal suatu perusahaan dalam industri atau nature of industry dapat digunakan untuk mendeteksi financial statement fraud.

Rasionalisasi merupakan elemen fraud diamond yang paling sulit untuk diteliti. Rasionalisasi menjadi elemen penting dalam terjadinya praktik kecurangan karena pelaku mencari pembenaran atas perbuatannya. Rasionalisasi membuat seseorang yang pada awalnya tidak akan melakukan tindakan kecurangan, berubah menjadi ingin melakukan tindakan tersebut. Rasionalisasi dapat digambarkan melalui penggunaan big 4 auditor. Dalam Statement of Auditing Standard (SAS) No. 99 menjelaskan bahwa hubungan manajemen dengan auditor merupakan rasionalisasi manajemen (AICPA, 2002).

Menurut Weiner (2012) ukuran perusahaan auditor mengindikasikan kredibilitas dan di sertai pengungkapan kecurangan perusahaan. Chen (2016) mengungkapkan bahwa auditor big 4 mengurangi insiden skandal keuangan pada perusahaan. Demikian pula diungkapkan oleh Fimanaya \& Syafruddin (2014) dalam penelitiannya diungkapkan bahwa ukuran perusahaan audit berpengaruh terhadap kemungkinan kecurangan pada laporan keuangan.

Capability merupakan suatu faktor kualitatif sebagai satu spelengkap dari model fraud triangle dari Cressey. Capability artinya seberapa besar daya dan 
kapasitas dari sifat individu melakukan penipuan, yang mendorong mereka untuk mecari kesempatan dan memanfaatkannya untuk melakukan fraud di lingkungan perusahaan (Wolfe \& Hermanson, 2004). Pergantian direksi atau change of directors tidak selamanya berdampak baik bagi perusahaan.

Pergantian direksi bisa menjadi suatu upaya perusahaan untuk memperbaiki kinerja direksi sebelumnya dengan melakukan perubahan susunan direksi atau perekrutan direksi yang baru yang dianggap lebih berkompeten dari direksi sebelumnya. Sementara disisi lain, pergantian direksi bisa jadi merupakan upaya perusahaan untuk menyingkirkan direksi yang dianggap mengetahui fraud yang dilakukan perusahaan serta pergantian direksi dianggap akan membutuhkan waktu adaptasi sehingga kinerja awal tidak maksimal.

Wolfe \& Hermanson (2004) mengemukakan bahwa pergantian direksi dapat menyebabkan stress period yang berdampak pada semakin terbukanya peluang untuk melakukan tindak kecurangan. Menurut (Putriasih, 2016) dalam penelitiannya menyatakan bahwa perubahan direksi berpengaruh atau dapat digunakan untuk mendeteksi financial statement fraud.

Penelitian ini akan dilakukan pada perusahaan manufaktur yang terdaftar di Bursa Efek Indonesia (BEI) periode 2015-2017. Pertimbangan memilih perusahaan manufaktur karena perusahaan manufaktur merupakan salah satu subsektor yang menjadi sumber penerimaan yang cukup besar dan memegang kendali dalam pertumbuhan ekonomi nasional. Disisi lain, perusahaan manufaktur sangat rentan akan terjadinya financial statement fraud (Dayana, 2012). Perusahaan manufaktur adalah perusahaan yang memiliki rantai proses bisnis yang lebih panjang dari industri lainnya, yaitu mengelola bahan mentah menjadi bahan jadi tentunya dalam pengukuran laporan keuangan mulai dari penentuan harga pokok produksi hingga harga pokok penjualan. Sehingga hal tersebut berimplikasi pada meningkatnya potensi kecurangan laporan keuangan.

Personal financial need merupakan suatu kondisi dimana keuangan perusahaan turut dipengaruhi oleh kondisi keuangan para eksekutif perusahaan (Kusumawardhani, 2013). Merujuk pada penelitian yang dilakukan oleh (Skousen et al., 2009), personal financial need dalam penelitian ini mengacu pada kebutuhan financial personal dari eksekutif perusahaan. Menurut Kusumaningsih (2017) dan Yusof et al., (2015) personal financial need dapat mempengaruhi tindak kecurangan karena kondisi keuangan perusahaan dipengaruhi oleh kondisi keuangan eksekutif perusahaan. Yamauchi \& Templer (1982) menggunakan money attitude scale (MAS) untuk mengukur sikap seseoranf terhadap uang dalam dimensi retention-time, memandang uang sebagai sumber daya yang harus diperlakukan secara berhati-hati untuk mecapai tujuan jangka panjang, karena hal tersebut mereka akan berhati-hati dan membuat perencanaan mengenai penggunaan uang yang dimilki. Sikap seseorang terhadap uang dimungkinkan dapat berdampak pada perilaku, kinerja, serta efektivitasnya dalam sebuah organisasi (Tang \& Firth, 2011).

Faktor personal financial need umumnya diproksikan dengan kepemilikan saham oleh orang dalam (OSHIP). Beasley (1996) menunjukkan bahwa ketika eksekutif perusahaan memiliki peranan keuangan yang kuat dalam perusahaan, personal financial need dari eksekutif perusahaan tersebut akan turut terpengaruh 
oleh kinerja keuangan perusahaan. Apabila kinerja perusahaan baik maka keadaan finansial personal dari eksekutif perusahaan, khususnya yang memiliki saham dalam perusahaan, juga baik. Sebaliknya apabila kinerja perusahaan buruk maka keadaan financial personal dari eksekutif perusahaan tersebut akan dapat terpengaruh buruk. Dengan sikap terhadap uang yang dimiliki, dimana eksekutif ingin menjamin bahwa keadaan finansial personalnya baik, maka eksekutif perusahaan akan memastikan bahwa kinerja perusahaan akan tetap baik dengan tidak melakukan tindakan yang dapat merugikan perusahaan, salah satunya tindak kecurangan.

Amara (2013) menyatakan bahwa tekanan yang dialami oleh eksekutif perusahaan mampu mempengaruhi peluang tindak kecurangan. Kusumaningsih (2017) mengungkapkan bahwa personal financial need yang diukur menggunakan variabel dummy berpengaruh negatif pada tindak kecurangan. Penelitian tersebut sejalan dengan Kusumaningrum (2016) yang diproksikan dengan insider's stock ownership berpengaruh negatif dalam mendeteksi kecurangan laporan keuangan. Hal tersebut didukung oleh penelitian dari Haryono (2017) dan Yulia (2016) bahwa personal financial need berpengaruh terhadap financial statement fraud. Berdasarkan penjelasan disusun hipotesis pertama dari penelitian ini yaitu, semakin tinggi personal financial need atau kepemilikan saham oleh orang dalam maka semakin rendah indikasi terjadinya financial statement fraud.

$\mathrm{H}_{1}$ : Personal financial need berpengaruh negatif pada indikasi financial statement fraud.

Nature of industry merupakan keadaan ideal suatu perusahaan dalam industri. Kondisi piutang usaha adalah bentuk dari nature of industry yang dapat direspon dengan reaksi yang berbeda-beda dari pihak manajer perusahaan. Summers \& Sweeney (1998) mencatat bahwa akun piutang dan persediaan memerlukan penilaian subjektif dalam memperkirakan tidak tertagihnya piutang dan obsolete inventory. Pada laporan keuangan terdapat akun-akun tertentu yang besarnya saldo ditentukan oleh perusahaan berdasarkan suatu estimasi, misalnya akun piutang tak tertagih dan persediaan using (Tiffani, 2015).

Menurut Summers \& Sweeney (1998) dalam Sihombing \& Rahardjo (2014) menyarankan bahwa karena adanya penilaian subjektif dalam menentukkan nilai dari akun tersebut, pihak manajemen dapat menggunakan akun tersebut sebagai alat untuk memanipulasi laporan keuangan, dan untuk mengurangi hal tersebut sangat diperlukan pengendalian atau pengawasan yang ketat dari pihak internal perusahaan. Pengendalian yang lemah akan memberikan kesempatan yang besar untuk terjadinya kecurangan (Donelson et al., 2017). Penelitian Summers \& Sweeney (1998) dalam (Skousen et al., 2009) mengukur nature of industry dengan menggunakan rasio total perubahan persediaan dan rasio perubahan total piutang..

Penelitian yang dilakukan oleh Kusumaningrum (2016) mengungkapkan bahwa nature of industry yang diukur dengan persentase perubahan total piutang pada penjualan memiliki pengaruh negatif terhadap deteksi kecurangan laporan keuangan. Putriasih (2016) menyatakan bahwa nature of industry berpengaruh untuk mendeteksi financial statement fraud, dan Haryono (2017) menyatakan bahwa nature of industry berpengaruh terhadap financial statement fraud. Berdasarkan penjelasan maka hipotesis kedua dari penelitian ini yaitu, semakin 
tinggi nature of industry atau keadaan ideal suatu perusahaan dalam industri maka semakin rendah indikasi terjadinya financial statement fraud.

$\mathrm{H}_{2}$ : Nature of industry berpengaruh negatif pada indikasi financial statement fraud.

Farber (2005) menunjukkan bahwa perusahaan yang melakukan fraud cenderung tidak memilih big four sebagai auditor eksternalnya. Penemuan ini membuktikan bahwa big four memiliki kualitas audit yang lebih baik dibandingkan auditor eksternal lainnya, dan juga mengurangi kesempatan perusahaan untuk melakukan kecurangan. KAP big 4 menjaga dengan baik reputasi dengan memberikan kualitas audit untuk meningkatkan kepercayaan masyarakat (Nizar, 2017). Becker et al., (1998) meneliti kualitas audit dengan jumlah discretionary accruals. Penelitian ini dilatarbelakangi studi bahwa non big six auditor mengijinkan lebih banyak earnings management dibandingkan big six auditor. Zhou dan Elder (dalam Antonia, 2008) menyatakan bahwa perusahaanperusahaan yang diaudit oleh KAP yang reputable memiliki kecenderungan tidak melakukan kecurangan sebelum proses IPO dibandingkan dengan perusahaanperusahaan yang diaudit oleh KAP big 4 . Hal tersebut menunjukkan bahwa memilih KAP big 4 merupakan penghalang bagi perusahaan untuk melakukan kecurangan.

Menurut Lennox \& Pittman (2010) dan Chen (2016) dalam penelitiannya mengungkapkan bahwa auditor big 4 mengurangi insiden skandal keuangan pada perusahaan. Weiner (2012) menyatakan bahwa ukuran perusahaan auditor mengindikasikan kredibilitas dan diikuti pengungkapan kecurangan perusahaan. Demikian juga yang diungkapkan oleh Fimanaya \& Syafruddin (2014) bahwa ukuran perusahaan audit berpengaruh terhadap kemungkinan kecurangan pada laporan keuangan. Berdasarkan penjelasan maka dapat disusun hipotesis ketiga dari penelitian ini yaitu, semakin besar auditor firm size atau perusahaan auditor yang diukur dengan KAP big 4 maka semakin kecil indikasi terjadinya financial statement fraud.

$\mathrm{H}_{3}$ : Auditor firm size berpengaruh negatif pada indikasi financial statement fraud.

Change of directors atau pergantian direksi bisa menjadi suatu upaya perusahaan untuk memperbaiki kinerja direksi sebelumnya dengan melakukan perubahan susunan direksi ataupun perekrutan direksi yang baru yang dianggap lebih berkompeten dari direksi sebelumnya. Sementara disisi lain, pergantian direksi bisa merupakan upaya perusahaan untuk menyingkirkan direksi yang dianggap mengetahui fraud yang dilakukan perusahaans serta pergantian direksi dianggap akan membutuhkan waktu adaptasi sehingga kinerja awal tidak maksimal.

Manurung \& Hardika (2015) menggunakan variabel pergantian direksi untuk mengetahui potensi kecurangan laporan keuangan. Penelitian tersebut berhasil membuktikan bahwa pergantian direksi berpengaruh positif signifikan terhadap potensi kecurangan laporan keuangan. Penelitian tersebut didukung oleh Zulvi \& Rustam (2017) menyatakan bahwa pergantian direksi memiliki pengaruh signifikan terhadap accounting irregularities, dan penelitian oleh Mardiani \& Edi (2017) mengungkapkan pergantin direksi memiliki pengaruh tehadap financial statement fraud. Berdasarkan pemaparan maka dapat disusun hipotesis empat dari penelitian ini yaitu, semakin sering change of directors atau 
pergantian direksi dalam suatu perusahaan maka semakin tinggi indikasi terjadinya financial statement fraud.

$\mathrm{H}_{4}$ : Change of directors berpengaruh positif pada indikasi financial statement fraud.

\section{METODE PENELITIAN}

Penelitian ini dilakukan pada perusahaan manufaktur yang terdaftar di Bursa Efek Indonesia (BEI) pada periode 2015-2017 dengan mengakses website Bursa Efek Indonesia yaitu pada www.idx.co.id. Obyek yang menjadi kajian dalam penelitian ini yaitu laporan tahunan perusahaan manufaktur yang terdaftar di Bursa Efek Indonesia (BEI) periode 2015-2017, berfokus pada informasi terkait dengan financial statement fraud, personal financial need, nature of industry, auditor firm size, dan change of directors.

Populasi dalam penelitian ini adalah seluruh perusahaan manufaktur yang terdaftar di BEI. Sampel yang digunakan adalah perusahaan manufaktur yang terdaftar di BEI yang dipilih melalui teknik purposive sampling dengan kriteria yang telah ditentukan sebagai berikut: a) Perusahaan manufaktur yang terdaftar di Bursa Efek Indonesia (BEI) periode 2015-2017. b) Mempublikasikan laporan keuangan tahunan yang berakhir pada 31 Desember dalam website perusahaan atau website Bursa Efek Indonesia selama periode 2015-2017. c) Laporan keuangan diaudit oleh auditor independen dan menggunakan rupiah sebagai mata uang pelaporan. d) Tidak delisting dari Bursa Efek Indonesia selama periode 2015-2017. e) Mengungkapkan data-data yang berkaitan dengan variabel penelitian dan tersedia secara lengkap pada publikasi periode 2015-2017.

Tabel 1. Definisi Operasional dan Pengukuran Variabel

\begin{tabular}{|c|c|c|}
\hline Variabel & Definisi & Pengukuran \\
\hline \multirow[t]{3}{*}{ Financial Statement Fraud } & Kecuranganyang & F-Score $=$ \\
\hline & dilakukanataslaporan & Accrual Quality + Financial \\
\hline & keuangan perusahaan. & Performance \\
\hline \multirow[t]{3}{*}{ Personal FinancialNeed } & Kebutuhan financial & OSHIP = Total saham yang \\
\hline & personal darieksekutif & $\frac{\text { dimiliki orang dalam }}{\text { Toliki }}$ \\
\hline & perusahaan. & $\begin{array}{l}\text { Total saham biasa yang } \\
\text { beredar }\end{array}$ \\
\hline \multirow[t]{3}{*}{ Auditor Firm Size } & \multirow{3}{*}{$\begin{array}{l}\text { Keadaan ideal suatu } \\
\text { perusahaan dalam } \\
\text { industri. }\end{array}$} & $\Delta$ Receivable $=$ \\
\hline & & Receivable $(t)$ \\
\hline & & Sales $(t-1)$ \\
\hline \multirow[t]{7}{*}{ Change of Directors } & Ukuran perusahaan & Skala nominal $=$ \\
\hline & $\begin{array}{l}\text { auditor yang dilihat dari } \\
\text { auditor big } 4 \text { dan auditor }\end{array}$ & $\begin{array}{l}1 \text { = Perusahaan diaudit oleh } \\
\text { big } 4\end{array}$ \\
\hline & non-big 4 . & $\begin{array}{l}0=\text { Perusahaan tidak diaudit } \\
\text { oleh big } 4\end{array}$ \\
\hline & Pergantian direksi yang & Skala nominal = \\
\hline & dilakukanoleh & $1=$ Terda pat pergantian \\
\hline & perusahaan untuk & direksi \\
\hline & $\begin{array}{l}\text { mengetahui potensi } \\
\text { adanya kecurangan. }\end{array}$ & $\begin{array}{l}0=\text { Tidak terdapat pergantian } \\
\text { direksi }\end{array}$ \\
\hline
\end{tabular}

Sumber: Data Penelitian, 2018 
Pengujian ini bertujuan untuk mengetahui pengaruh personal financial need, nature of industry, auditor firm size, dan change of directors pada indikasi financial statement fraud. Bentuk regresi ini dirancang untuk menentukan hubungan antara dua variabel yang dipengaruhi oleh variabel dependen (Ghozali, 2016:213). Secara sistematis, persamaan regresi yang diperoleh yakni: Keterangan:

$$
Y=\alpha+\beta_{1} X_{1}+\beta_{2} X_{2}+\beta_{3} X_{3}+\beta_{4} X_{4}+\varepsilon
$$

$$
\begin{array}{ll}
\mathrm{Y} & =\text { Financial Statement Fraud } \\
\mathrm{a} & =\text { Konstanta } \\
\beta & =\text { Koefisien regresi } \\
\mathrm{X}_{1} & =\text { Personal Financial Need } \\
\mathrm{X}_{2} & =\text { Nature of Industry } \\
\mathrm{X}_{3} & =\text { Auditor Firm Size } \\
\mathrm{X}_{4} & =\text { Change of Directors } \\
\varepsilon & =\text { Error }
\end{array}
$$

\section{HASIL DAN PEMBAHASAN}

Pengambilan sampel dalam penelitian ini menggunakan metode nonprobability

\begin{tabular}{|c|c|c|}
\hline No & Kriteria & Jumlah Perusahaan \\
\hline 1 & $\begin{array}{l}\text { Perusahaan manufaktur yang terdaftar di Bursa Efek } \\
\text { Indonesia (BEI) periode 2015-2017 }\end{array}$ & 145 \\
\hline 2 & $\begin{array}{l}\text { Perusahaan manufaktur yang pelaporan keuangan } \\
\text { tahunan tidak berakhir pada 31 Desember }\end{array}$ & $(25)$ \\
\hline 3 & $\begin{array}{l}\text { Perusahaan manufaktur tidak menggunakan rupiah } \\
\text { sebagai mata uang pelaporan }\end{array}$ & $(28)$ \\
\hline 4 & $\begin{array}{l}\text { Perusahaan manufaktur yang delisting dari BEI selama } \\
\text { periode 2015-2017 }\end{array}$ & (3) \\
\hline 5 & $\begin{array}{l}\text { Perusahaan manufaktur tidak memiliki kelengkapan data } \\
\text { mengenai variabel-variabel yang diteliti dalam penelitian }\end{array}$ & (4) \\
\hline \multicolumn{2}{|c|}{ Jumlah perusahaan yang terpilih sebagai sampel } & 85 \\
\hline \multicolumn{2}{|c|}{ Total sampel dalam tiga tahun pengamatan } & 255 \\
\hline \multicolumn{2}{|c|}{ Data yang outlier } & (57) \\
\hline \multicolumn{2}{|c|}{ Total sampel dalam tiga tahun penelitian } & 198 \\
\hline
\end{tabular}
sampling dengan teknik purposive sampling. Berdasarkan hasil observasi dokumentasi, maka perusahaan yang dapat dijadikan sampel adalah sebanyak 85 perusahaan, diobservasi selama 3 tahun. Dengan demikian, diperoleh 255 sampel. Terdapat data yang mengandung outlier sebanyak 57 observasian dikarenakan nilai standar residual yang tinggi sehingga perlu dikeluarkan dari pengujian. Dengan demikian diperoleh 198 observasian. Proses seleksi sampel dengan menggunakan teknik purposive sampling disajikan pada Tabel 2.

Tabel 2. Hasil Penentuan Seleksi Sampel Penelitian

Sumber: Data Penelitian, 2018

Financial statement fraud yang diukur menggunakan fraud score model yang merupakan penjumlahan dari accrual quality (kualitas akrual) dan financial performance (kinerja keuangan). Semakin tinggi nilai kecurangan (F-Score) maka semakin tinggi risiko kecurangan perusahaan tersebut. Nilai minimum financial statement fraud sebesar - 0,5995 serta nilai maksimum sebesar 1,1636. Perusahaan dengan nilai financial statement fraud terendah adalah Tiga Pilar Sejahtera Food 
pada tahun 2017, sedangkan perusahaan dengan nilai financial statement fraud teritinggi yaitu Tri Banyan Tirta pada tahun 2017. Nilai mean untuk financial statement fraud sebesar 0,041222. Nilai mean financial statement fraud lebih mendekati nilai minimum. Hal tersebut berarti rata-rata financial statement fraud perusahaan manufaktur cenderung rendah. Rata-rata 4,12 persen perusahaan manufaktur melakukan financial statement fraud dalam kurun waktu 2015 hingga 2017. Deviasi standar adalah gambaran tingkat variasi data dan tingkat variasi data indikator F-Score adalah sebesar 0,2155111. Deviasi standar financial statement fraud lebih besar dari pada nilai rata-rata, artinya ada fluktuasi tinggi pada financial statement fraud perusahaan manufaktur yang menjadi sampel. Hasil dari statistik deskriptif disajikan pada Tabel 3 berikut.

Tabel 3. Hasil Uji Statistik Deskriptif Variabel Penelitian

\begin{tabular}{lrrrrr}
\hline & N & Minimum & Maximum & \multicolumn{1}{c}{ Mean } & Std. Deviation \\
\hline Y & 198 & $-0,5995$ & 1,1636 & 0,041222 & 0,2155111 \\
X1 & 198 & 0,0000 & 2,5589 & 0,103134 & 0,3232452 \\
X2 & 198 & $-0,1771$ & 0,1035 & 0,004840 & 0,0351434 \\
X3 & 198 & 0,0000 & 1,0000 & 0,444444 & 0,4981636 \\
X4 & 198 & 0,0000 & 1,0000 & 0,313131 & 0,4649429 \\
Valid N(listwise) & 198 & & & & \\
\hline
\end{tabular}

Sumber: Data Penelitian, 2018

Personal financial need yang diproksikan dengan OSHIP yaitu persentase kumulatif dari kepemilikan pada perusahaan yang dimiliki oleh orang dalam. Semakin tinggi nilai OSHIP maka semakin besar kepemilikan saham oleh orang dalam perusahaan tersebut. Nilai minimum personal financial need sebesar 0,0000 nilai ini diperoleh oleh perusahaan yang tidak menerapkan kepemilikan saham oleh orang dalam perusahaan, serta nilai maksimumnya sebesar 2,5589 yaitu perusahaan Lionmesh Prima pada tahun 2015. Nilai mean atau rata-rata untuk personal financial need sebesar 0,103134. Nilai rata-rata personal financial need lebih mendekati nilai minimum. Hal ini menandakan rata-rata kepemilikan saham oleh orang dalam perusahaan manufaktur cenderung rendah. Rata-rata 10,3 persen saham perusahaan manufaktur yang beredar dimiliki oleh orang dalam perusahaan seperti karyawan, manajer, dan direksi. Deviasi standar sebesar 0,3232452. Deviasi standar personal financial need lebih besar dari nilai rata-rata, artinya ada fluktuasi tinggi pada personal financial need perusahaan manufaktur yang menjadi sampel.

Nature of industry yang diproksikan dengan $\triangle$ RECEIVABLE yaitu perbandingan total piutang dan penjulan $(t)$ dengan $(t-1)$. Semakin tinggi nilai $\triangle$ RECEIVABLE maka semakin tinggi pengungkapan total piutang dan penjualan pada perusahaan tersebut. Nilai minimum nature of industry sebesar - 0,1771 yaitu pada perusahaan Tri Banyan Tirta tahun 2017. Nilai maksimum nature of industry sebesar 0,1035 yaitu pada perusahaan Tiga Pilar Sejahtera Food tahun 2017. Rata-rata atau mean untuk nature of industry sebesar 0,004840. Nilai rata-rata nature of industry lebih mendekati nilai minimum, artinya rata-rata pengungkapan total piutang dan penjualan dalam perusahaan manufaktur cenderung rendah. Rata-rata 0,48 persen perusahaan manufaktur melakukan pengungkapan total piutang dan penjualan. Nilai deviasi standar sebesar 0,0351434. Deviasi standar nature of industry lebih besar dari nilai rata-rata, 
artinya ada fluktuasi tinggi pada nature of industry perusahaan manufaktur yang menjadi sampel.

Auditor firm size diukur menggunakan variabel dummy (skala nominal) yaitu dengan memberikan kode 1 untuk perusahaan yang diaudit oleh auditor big 4 dan memberikan kode 0 untuk perusahaan yang tidak diaudit oleh auditor big 4. Terdapat 88 perusahaan manufaktur yang diaudit oleh auditor big 4 dan 110 perusahaan yang tidak diaudit oleh auditor big 4 dalam kurun waktu 2015-2017. Mean atau nilai rata-rata untuk auditor firm size sebesar 0,444444. Nilai rata-rata auditor firm size lebih mendekati nilai minimum. Hal tersebut menandakan bahwa rata-rata perusahaan manufaktur yang diaudit oleh auditor big 4 sebesar 44,44 persen. Deviasi standar sebesar 0,4981636. Deviasi standar auditor firm size lebih besar dari nilai rata-rata hal tersebut menunjukkan bahwa auditor firm size dengan kode 1 lebih sedikit muncul 44,44 persen yang diaudit oleh auditor big 4 dan sebesar 55,56 persen perusahaan manufaktur yang menjadi sampel tidak diaudit oleh auditor big 4.

Change of directors atau pergantian direksi diukur menggunakan variabel dummy (skala nominal) yaitu dengan memberikan kode 1 untuk perusahaan yang melakukan pergantian direksi, dan memberikan kode 0 untuk perusahaan yang tidak melakukan pergantian direksi. Terdapat 62 perusahaan manufaktur yang melakukan pergantian direksi dalam kurun waktu 2015 hingga 2017 dan 136 perusahaan manufaktur yang tidak melakukan pergantian direksi. Nilai mean atau rata-rata change of directors sebesar 0,313131. Nilai rata-rata change of directors lebih mendekati nilai minimum. Hal tersebut menandakan bahwa ratarata perusahaan manufaktur yang menjadi sampel kurun waktu 2015-2017 yang melakukan pergantian direksi sebesar 31,31 persen. Deviasi standar sebesar 0,4649429 . Deviasi standar change of directors lebih besar dari nilai rata-rata hal tersebut menunjukkan bahwa change of directors dengan kode 1 lebih sedikit muncul yaitu sebesar 31,31 persen yang melakukan pergantian direksi dan 68,69 persen perusahaan manufaktur tidak melakukan pergantian direksi. Rekapitulasi hasil analisis regresi linier berganda disajikan pada Tabel 4 berikut.

Tabel 4. Rekapitulasi Hasil Regresi Linier Berganda

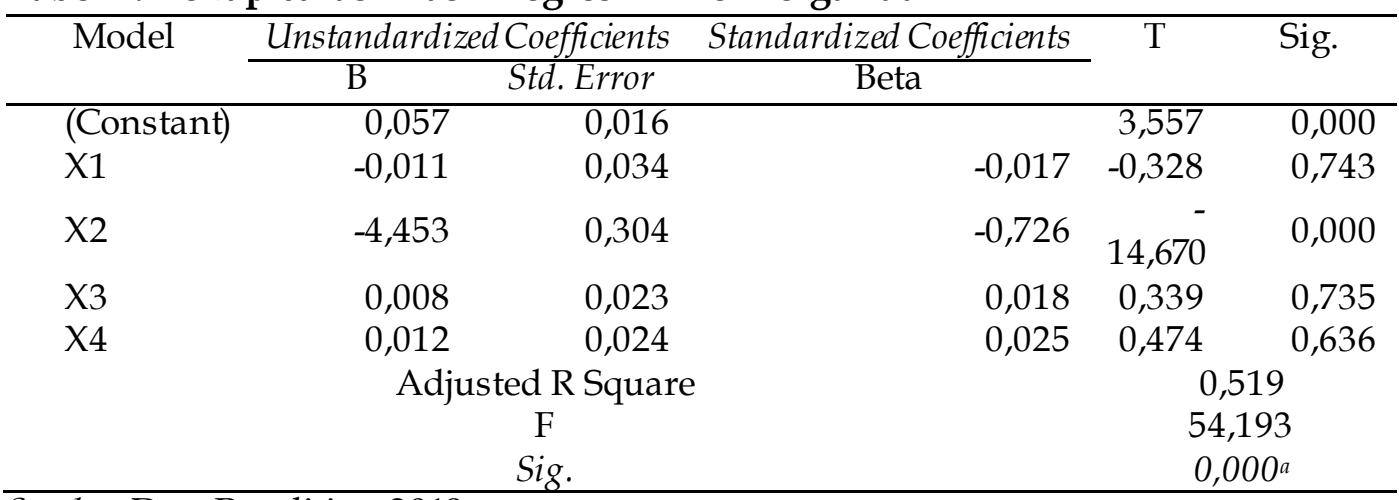

Sumber: Data Penelitian, 2018

Berdasarkan informasi pada Tabel 4 maka dapat dirumuskan persamaan regresi seperti berikut ini.

$\mathrm{Y}=0,057-0,011 \mathrm{X}_{1}-4,453 \mathrm{X}_{2}+0,008 \mathrm{X}_{3}+0,012 \mathrm{X}_{4}+\varepsilon$

Hasil pengujian kelayakan model menunjukkan bahwa nilai Sig. sebesar 0,000 . Nilai tersebut lebih kecil dari nilai $a=0,05$ sehingga disimpulkan bahwa 
model persamaan dalam penelitian ini layak digunakan. Koefisien determinasi ditunjukkan oleh nilai $R$ Square sebesar 0,519. Hal ini berarti bahwa 51,9 persen variasi perubahan dari variabel dependen yaitu indikasi financial statement fraud dapat dijelaskan oleh variabel independen yaitu personal financial need, nature of industry, auditor firm size, dan change of directors. Sedangkan sisanya sebesar 48,1 persen dipengaruhi oleh faktor-faktor lain yang tidak dimasukkan ke dalam model regresi yang digunakan.

Hipotesis pertama $\left(\mathrm{H}_{1}\right)$ dalam penelitian ini menyatakan bahwa personal financial need berpengaruh negatif pada indikasi financial statement fraud. Hasil analisis dengan menggunakan regresi linier berganda yang terdapat pada Tabel 3, variabel personal financial need yang diproksikan dengan OSHIP memiliki tingkat siginifikansi sebesar 0,743 yaitu lebih besar dari a $=0,05$ atau 0,743>0,05 hal tersebut menunjukkan bahwa personal financial need tidak berpengaruh pada indikasi financial statement fraud. Besar kecilnya proporsi saham perusahaan manufaktur yang dimiliki oleh orang dalam perusahaan tidak berdampak pada indikasi kecurangan laporan keuangan.

Hasil ini tidak mendukung dari hipotesis yang menyatakan bahwa personal financial need berpengaruh negatif pada indikasi financial statement fraud. Hal ini dikarenakan sedikitnya perusahaan yang menerapkan kepemilikan saham orang dalam pada perusahaan manufaktur kurun waktu 2015 hingga 2017, sehingga hal tersebut mempengaruhi indikasi financial statement fraud. Hasil penelitian ini tidak sejalan dengan teori fraud diamond. Fraud diamond theory menyatakan bahwa tekanan yang diproksikan melalui personal financial need dapat mempengaruhi tindak kecurangan karena kondisi keuangan perusahaan turut dipengaruhi oleh kondisi keuangan para eksekutif perusahaan (Kusumaningrum, 2016).

Hasil penelitian ini sesuai dengan penelitian yang dilakukan oleh Norbarani (2012) dan Rachmania (2016) yang menyatakan bahwa personal financial need tidak berpengaruh terhadap kecurangan laporan keuangan yang diproksikan dengan manajemen laba, serta penelitian yang dilakukan oleh Zulvi dan Rustam (2017) yang mengatakan bahwa personal financial need tidak berpengaruh signifikan terhadap tingkat accounting irregularities yang diproksikan dengan persentase kepemilikan saham orang dalam.

Hasil penelitian ini tidak mendukung penelitian yang dilakukan oleh Kusumaningsih (2017) yang menyatakan bahwa personal financial need yang diukur dengan ada atau tidaknya kepemilikan saham pihak internal terbukti berpengaruh negatif dan dapat mengurangi terjadinya tindak kecurangan, dan penelitian Yusof (2015) yang menyatakan bahwa personal financial need dapat mempengaruhi tindak kecurangan karena kondisi keuangan perusahaan turut dipengaruhi oleh kondisi keuangan para eksekutif perusahaan.

Hipotesis kedua $\left(\mathrm{H}_{2}\right)$ dalam penelitian ini menyatakan bahwa nature of industry berpengaruh negatif pada indikasi financial statement fraud. Hasil analisis dengan menggunakan regresi linier berganda yang terdapat pada Tabel 3, variabel nature of industry yang diproksikan dengan $\triangle$ RECEIVABLE yaitu perbandingan total piutang dan penjulan $(t)$ dengan $(t-1)$ memiliki tingkat siginifikansi sebesar 0,000 yaitu lebih kecil dari $a=0,05$ atau 0,000<0,05 hal tersebut menunjukkan bahwa nature of industry berpengaruh pada indikasi 
financial statement fraud. Arah koefisien regresi variabel nature of industry dalam penelitian ini bertanda negatif sebesar $-4,453$.

Hasil analisis menunjukkan bahwa nature of industry berpengaruh signifikan negatif pada indikasi financial statement fraud. Semakin tinggi nature of industry atau keadaan ideal suatu perusahaan dalam industri menyebabkan indikasi terjadinya financial statement fraud menurun. Hasil ini mendukung hipotesis yang menyatakan bahwa nature of industry berpengaruh negatif pada indikasi financial statement fraud. Hasil penelitian ini mendukung teori fraud diamond dan good corporate governance yang menyatakan bahwa kesempatan dapat meningkatkan risiko terjadinya praktik kecurangan dalam perusahaan.

Hasil penelitian ini sesuai dengan hasil penelitian yang dilakukan oleh Kusumaninggrum (2016) yang menyatakan bahwa nature of industry memiliki pengaruh negatif terhadap deteksi kecurangan laporan keuangan. Penelitian tersebut sejalan dengan penelitian yang dilakukan oleh Rahmawati (2013) dan Adiwitarsa (2011).

Hipotesis ketiga $\left(\mathrm{H}_{3}\right)$ dalam penelitian ini menyatakan bahwa auditor firm size berpengaruh negatif pada indikasi financial statement fraud. Hasil analisis dengan menggunakan regresi linier berganda yang terdapat pada Tabel 3, variabel auditor firm size yang diukur menggunakan variabel dummy (skala nominal) memiliki tingkat siginifikansi sebesar 0,735 yaitu lebih besar dari $\alpha=$ 0,05 atau 0,735>0,05 hal tersebut menunjukkan bahwa auditor firm size tidak berpengaruh pada indikasi financial statement fraud. Ukuran perusahaan auditor, baik auditor big 4 maupun auditor non big 4 yang mengaudit perusahaan manufaktur yang menjadi sampel tidak berdampak pada praktik kecurangan laporan keuangan.

Hasil ini tidak mendukung dari hipotesis yang menyatakan bahwa auditor firm size berpengaruh negatif pada indikasi financial statement fraud. Hal ini dikarenakan sedikitnya perusahaan yang diaudit oleh auditor big 4 pada perusahaan manufaktur terdapat 88 perusahaan manufaktur yang diaudit oleh auditor big 4 dan 110 perusahaan yang tidak diaudit oleh auditor big 4 dalam kurun waktu 2015-2017, sehingga hal tersebut mempengaruhi indikasi financial statement fraud. Hasil penelitian ini tidak sesuai dengan teori yang digunakan yaitu fraud diamond theory dan good corporate governance.

Rasionalisasi dalam teori fraud diamond yang diproksikan melalui auditor firm size dapat mengurangi terjadinya kecurangan. Menurut Nizar (2017) dan Nariman (2015) KAP big 4 menjaga betul reputasi dengan memberikan kualitas audit untuk meningkatkan kepercayaan masyarakat. Kepercayaan masyarakat dapat meningkat melalui prinsip-prinsip yang terdapat pada penerapan corporate governance yaitu melalui transparansi, akuntabilitas, responsibilitas, independensi dan kesetaraan perusahaan yang meningkat. Hasil penelitian ini sesuai dengan penelitian yang dilakukan oleh Verdiana (2013), Hartadi (2012), dan Nindita (2012) yang mengungkapkan bahwa ukuran perusahaan auditor tidak berpengaruh signifikan terhadap kualitas audit.

Hipotesis keempat $\left(\mathrm{H}_{4}\right)$ dalam penelitian ini menyatakan bahwa change of directors berpengaruh negatif pada indikasi financial statement fraud. Hasil analisis dengan menggunakan regresi linier berganda yang terdapat pada Tabel 3 variabel change of directors yang diukur menggunakan variabel dummy (skala 
nominal) memiliki tingkat siginifikansi sebesar 0,636 yaitu lebih besar dari a $=$ 0,05 atau 0,636>0,05 hal tersebut menunjukkan bahwa change of directors tidak berpengaruh pada indikasi financial statement fraud. Ada maupun tidaknya pergantian direksi atau change of directors pada perusahaan manufaktur yang menjadi sampel tidak berdampak pada praktik kecurangan laporan keuangan.

Hasil ini tidak mendukung dari hipotesis yang menyatakan bahwa change of directors berpengaruh positif pada indikasi financial statement fraud. Hal ini dikarenakan sedikitnya perusahaan yang melakukan pergantian direksi pada perusahaan manufaktur kurun waktu 2015 hingga 2017 yaitu sebesar 62 perusahaan manufaktur dari 198 perusahaan manufaktur yang menjadi observasian sehingga hal tersebut mempengaruhi indikasi terjadinya financial statement fraud. Hasil penelitian ini sejalan dengan penelitian yang dilakukan oleh Aulia (2018) yang mengatakan bahwa pergantian direksi tidak berpengaruh dalam mendeteksi potensi kecurangan laporan keuangan. Penelitian ini sejalan dengan penelitian yang dilakukan oleh Asmarani (2016) dan Zaki (2017).

\section{SIMPULAN}

Berdasarkan hasil analisis, simpulan yang dapat disampaikan oleh peneliti bahwa personal financial need tidak berpengaruh pada indikasi terjadinya financial statement fraud. Hal ini menunjukkan bahwa persentase pada jumlah kepemilikan saham oleh orang dalam perusahaan tidak akan mempengaruhi indikasi terjadinya kecurangan atas laporan keuangan perusahaan manufaktur periode 2015-2017.

Nature of industry berpengaruh negatif pada indikasi terjadinya financial statement fraud. Hal ini menunjukkan bahwa semakin tinggi nature of industry atau keadaan ideal suatu perusahaan dalam industri maka peluang terjadinya kecurangan atas laporan keuangan akan menurun.

Auditor firm size tidak berpengaruh pada indikasi terjadinya financial statement fraud. Hal ini menunjukkan bahwa baik perusahaan yang diaudit oleh auditor big 4 ataupun auditor non big 4 maka tidak akan mempengaruhi indikasi terjadinya kecurangan atas laporan keuangan perusahaan manufaktur periode 2015-2017.

Change of directors tidak berpengaruh pada indikasi terjadinya financial statement fraud. Hal ini menunjukkan bahwa ada atau tidaknya pergantian direksi pada perusahaan manufaktur yang menjadi sampel maka tidak akan mempengaruhi indikasi terjadinya kecurangan atas laporan keuangan perusahaan manufaktur periode 2015-2017.

Berdasarkan simpulan, saran-saran yang dapat disampaikan kepada peneliti selanjutnya yaitu diketahui bahwa hasil penelitian ini tidak dapat digeneralisasi untuk seluruh perusahaan yang terdaftar di Bursa Efek Indonesia, karena penelitian ini hanya menggunakan perusahaan manufaktur sebagai ruang lingkup penelitian, sehingga penelitian selanjutnya disarankan untuk menggunakan ruang lingkup sektor lainnya, seperti sektor pertambangan, sektor keuangan, sektor perbankan, dan lain-lain. Bagi peneliti selanjutnya dapat menggunakan variabel-variabel lainnya yang menjadi faktor-faktor mempengaruhi indikasi terjadinya financial statement fraud pada suatu 
perusahaan. Faktor-faktor tersebut diharapkan merupakan refleksi dari elemen tekanan, rasionalisasi, dan kemampuan dalam teori fraud diamond.

Peneliti selanjutnya dapat menggunakan proksi lain dari variabel seperti variabel kualitas audit untuk menggantikan variabel auditor firm size karean penelitian ini menunjukkan bahwa ukuran perusahaan audit tidak berpengaruh terhadap indikasi terjadinya kecurangan atas laporan keuangan. Peneliti selanjutnya dapat memperpanjang tahun pengamatan agar dapat melihat kecenderungan yang terjadi dalam jangka waktu yang lebih panjang, karena tahun pengamatan penelitian ini hanya dilakukan selama tiga tahun.

Bagi seluruh shareholder, pemerintah, maupun pihak-pihak lainnya yang memanfaatkan informasi dari laporan keuangan perusahaan untuk mengambil keputusan diharapkan mampu memperhatikan faktor-faktor yang mempengaruhi kecurangan atas laporan keuangan khususnya nature of industry atau keadaan ideal suatu perusahaan dalam industri . Nature of industry pada perusahaan harus diperhatikan sehingga investor maupun pengguna laporan keuangan tidak mengambil keputusan yang salah yang dapat merugikan.

\section{REFERENSI}

ACFE. (2016). Association of Certified Fraud Examination (ACFE). ACFE Reports The Nation. New York.

AICPA. (2002). Statement on Auditing Standards: SAS No. 99. AU Sections 316, Consideration of Fraud in A Financial Statement Audit.

Amara, I., \& Amar, A. B. E. N. (2013). Detection of Fraud in Financial Statements: French Companies as a Case Study. International Journal of Academic Research in Business and Social Sciences, 3(5), 456-472.

Aulia, H. (2018). Analisis Fraud Diamond Dalam Mendeteksi Potensi Kecurangan Laporan Keuangan (Studi pada Perusahaan Manufaktur yang Terdaftar di BEI Tahun 2014-2016). Fakultas Ekonomi Universitas Islam Indonesia.

Asmarani, Y. \& Annisya, M. Lindrianasari. (2016). Pendeteksian Kecurangan Laporan Keuangan Menggunakan Fraud Diamond. Jurnal Bisnis dan Ekonomi (JBE), 23(1), 72-89.

Beasley, M. S. (1996). Empirical Analysis the of Board the Relation of Financial Between Composition Statement Fraud. The Accounting Review, 71(4), 443465.

Becker, C. L., Defond, M. L., \& California, S. (1998). The Effect of Audit Quality on Earnings Management. Contemporary Accounting Research, 15(1), 1-24. https://doi.org/10.1111/j.1911-3846.1998.tb00547.x

Chen, L. (2016). Local Institutions, Audit Quality, and Corporate Scandals of US-listed Foreign Firms. Journal of Business Ethics, 133, 351-373.

Donelson, D. Ege, M., \& Mcinnis, J. M. (2017). Internal Control Weaknesses and Financial Reporting Fraud Dain. Auditing, (36), 45-69.

Farber, D. B. (2005). Restoring Trust After Fraud : Does Corporate Governance Mattr? Accounting Review, 80, 539-561. https://doi.org/10.2308/ajpt-51608

Fimanaya, F., \& Syafruddin, M. (2014). Analisis Faktor-Faktor yang Mempengaruhi Kecurangan Laporan Keuangan. Diponegoro Journal of Accounting, 3(99), 1-11. 
Ghozali, Imam. 2016. Aplikasi Analisis Multivariate dengan Program SPSS. Semarang: Badan Penerbit Universitas Diponegoro.

H, A. K. A., Simon, J., \& Mohamed Yusof, K. (2015). Fraudulent Financial Reporting: An Application of Fraud Models to Malaysian Public Listed Companies, 4(3), 126-145.

Hartadi, B. (2012). Pengaruh Fee Audit, Rotasi KAP, dan Reputasi Auditor Terhadap Kualitas Audit di Bursa Efek Indonesia. Jurnal Ekonomi Dan Keuangan, 16(1), 84-102.

Haryono, M. E. (2017). Analisis Fraud Triangle dalam Mendeteksi Financial Statement Fraud. Jurnal Akuntansi Dan Auditing, 9(2).

Kusumaningrum, A. W. (2016). Analisis Pengaruh Fraud Diamond dalam Mendeteksi Kecurangan Laporan Keuangan. Invesment Challenges And Opportunities In Indonesian Capital Market In The Era Of Asean Economic Community, (September), 125-138.

Kusumaningsih, K.U., \& Wirajaya, I G. A. (2017). Faktor-faktor yang Mempengaruhi Tindak Kecurangan di Perusahaan Perbankan. E-Jurnal Akuntansi Universitas Udayana, 19(1), 1832-1860.

Kusumawardhani, P. (2013). Deteksi Financial Statement Fraud dengan Analisis Fraud Triangle pada Perusahaan Perbankan yang Terdaftar di BEI. Jurnal Akuntansi Universitas Negeri Surabaya, 1(3).

Lennox, C., \& Pittman, J. (2010). Big Five Audits and Accounting Fraud. Contemporary Accounting Research, 27, 209-247. https://doi.org/10.2139/ssrn.1137829

Manurung, D. T. H., \& Hardika, A. L. (2015). Analysis of factors that influence financial statement fraud in the perspective fraud diamond: Empirical study on banking companies listed on the Indonesia Stock Exchange year 2012 to 2014. In International Conference on Accounting Studies (ICAS) (pp. 280-286).

Mardiani, S., \& Edi, S. T. (2017). Pengaruh Fraud Diamond terhadap Pendeteksian Financial Statement Fraud dengan Komite Audit Sebagai Variabel Moderasi (pada Perusahaan Sub Sektor Farmasi yang Terdaftar di Bursa Efek Indonesia). Prosiding Akuntansi, 3(2), 476-484.

Nariman, A. (2015). Pengaruh Ukuran Kantor Akuntan Publik Terhadap Opini Going Concern dan Earnings Response Coefficient (ERC) Perusahaan Manufaktur yang Terdaftar di BEI Tahun 2011-2013. Jurnal Akuntansi, XIX(2), 160-178.

Nindita, C., \& Siregar, S. V. (2012). Analisis Pengaruh Ukuran Kantor Akuntan Publik Terhadap Kualitas Audit di Indonesia. Jurnal Akuntansi Dan Keuangan, 14(2), 91-104.

Nizar, A. A. (2017). Pengaruh Rotasi, Reputasi dan Spesialisasi Auditor terhadap Kualitas Audit (Studi Empiris pada Perusahaan Manufaktur yang Listed di BEI). Jurnal Nasional UMP, XV(2), 157-172.

Norbarani, L. (2012). Pendeteksian Kecurangan Laporan Keuangan dengan Analisis Fraud Triangle yang Diadopsi Dalam SAS nO.00. Ekonomika Dan Bisnis, (99), 69.

Putriasih, K., Herawati, N. N. T., \& Wahyuni, M. A. (2016). Analisis Fraud Diamond Dalam Mendeteksi Financial Statement Fraud : Studi Empiris Pada Perusahaan Manufaktur Yang Terdaftar Di Bursa Efek Indonesia (Beu) 
Tahun 2013-2015. E-JournalS1 Ak Universitas Pendidikan Ganesha, 6(3).

Rachmania, A. (2016). Analisis Pengaruh Fraud Triangle Terhadap Kecurangan Laporan Keuangan Pada Perusahaan Makanan dan Minuman Yang Terdaftar di Bursa Efek Indonesia Periode 2013-2015.

Sari, K. G. A., Wirakusuma, M. G., \& Ratnadi, N. M. D. (2018). Pengaruh Skeptisisme Profesional, Etika, Tipe Kepribadian, Kompensasi, dan Pengalaman pada Pendeteksian Kecurangan, 1(7), 29-56.

Sihombing, K. S., \& Rahardjo, S. N. (2014). Analisis Fraud Diamond dalam Mendeteksi Financial Statement Fraud : Studi Empiris pada Perusahaan Manufaktur yang Terdaftar di Bursa Efek Indonesia (BEI) Tahun 2010-2012. Diponegoro Journal of Accounting, 3(2), 1-12.

Skousen, C. J., Smith, K. R., \& Wright, C. J. (2009). Detecting and Predicting Financial Statement Fraud The Effectiveness of The Fraud Triangle and SAS No. 99. In Corporate Governance and Firm Performance, 13, 53-82.

Summers, S. L., \& Sweeney, J. T. (1998). Fraudulently misstated financial statements and insider trading: An empirical Analysis. The Accounting Review, 73(1), 131-146.

Surya Utama, I. G. P. O., Ramantha, I. W., \& Badera, I. D. N. (2018). Analisis Faktor-Faktor Dalam Perspektif Fraud Triangle Sebagai Prediktor Fraudulent Financial Reporting. E-Jurnal Ekonomi Dan Bisnis Universitas Udayana, 7(1), 251-278.

Tang, T., \& Firth, M. (2011). Can book - tax differences capture earnings management and tax Management? Empirical evidence from China. International Journal of Accounting, 46(2), 175-204. https://doi.org/10.1016/j.intacc.2011.04.005

Tiffani, L. (2015). Deteksi Financial Statement Fraud dengan Analisis Fraud Traingle pada Perusahaan Manufaktur yang Terdaftar di Bursa Efek Indonesia. Jurnal Akuntansi Dan Auditing Indonesia, 19(2), 112-125.

Verdiana, K. A. (2013). Pengaruh Reputasi Auditor, Disclosure, Audit Client Tenure pada Kemungkinan Pengungkapan Opini Audit Going Concern. EJurnal Akuntansi Universitas Udayana, 5(3), 530-543.

Weiner, J. (2012). Auditor Size vs . Audit Quality : An Analysis of Auditor Switches. Thesis from Honors College. Netherlands.

Wolfe, D. T., \& Hermanson, D. R. (2004). The Fraud Diamond : Considering the Four Elements of Fraud. The CPA Journal, 74(12), 38-42.

Yamauchi, K. T., \& Templer, D. J. (1982). The Development of a Money Attitude Scale. Journal of Personality Assessment, 46(5), 522-528. https://doi.org/10.1207/s15327752jpa4605

Yulia, A. W., \& Basuki. (2016). Studi Financial Statement Fraud pada Perbankan yang Terdaftar di Bursa Efek Indonesia. Jurnal Ekonomi Dan Bisnis, (2), 187200.

Zulvi, N., \& Rustam, H. (2017). Analisis Pengaruh Fraud Diamond dalam Mendeteksi Tingkat Accounting Irregularities. Jurnal Akuntansi Indonesia, 6(2), 167-184. 